Aneta Makowiec

Uniwersytet Jagielloński

Artur Górski

\title{
Giełda Papierów Wartościowych w Warszawie - jej rola w gospodarce Polski i perspektywy rozwoju
}

\section{Zagadnienia wprowadzające. Historia Giełdy Papierów Wartościowych w Warszawie}

Historia giełdy papierów wartościowych w Polsce sięga 1817 r. Pierwsza giełda działająca na ziemiach polskich została otwarta dokładnie 12 maja 1817 r. w Warszawie. Działała ona aż do 1939 r. ${ }^{1}$ Sesje giełdowe w końcu lat 20. odbywały się dwa razy dziennie. Od 11.15 do 12.15 notowano papiery wartościowe, zaś od 12.30 do 13.00 dewizy zagraniczne ${ }^{2}$. Obrót akcjami rozwinął się dopiero w drugiej połowie XIX w. Giełda ta odgrywała bardzo ważną rolę w rozwoju gospodarczym Królestwa Polskiego. W okresie dwudziestolecia międzywojennego w Polsce działało siedem giełd papierów wartościowych ${ }^{3}$. Mieściły się one w: Krakowie, Katowicach, Poznaniu, Łodzi, Lwowie i Wilnie. Giełda krakowska opierała się - aż do wprowadzenia w życie polskiej ustawy regulującej działalność giełd pieniężnych - na austriackiej ustawie z 1 kwietnia 1875 r. o organizacji giełd. Pomimo istnienia innych giełd w Polsce, aż 90\% publicznych obrotów papierami wartościowymi odbywało się na Giełdzie Pieniężnej w Warszawie ${ }^{4}$. W 1938 r. notowano na niej ok. sto trzydzieści instrumentów finansowych, m.in. obligacje państwowe, obligacje bankowe, obligacje municypalne, listy zastawne oraz akcje ${ }^{5}$. Rynek giełdowy $\mathrm{w}$ Polsce $\mathrm{w}$ okresie dwudziestolecia międzywojennego dość dobrze się rozwinął. Podstawowym aktem prawnym regulującym działalność giełd papierów

\footnotetext{
${ }^{1}$ Cf. T. Włudyka, Dwa dwudziestolecia gospodarki rynkowej w Polsce, Warszawa 2008, s. 112-122.

2 Ibidem, s. 119.

3 Cf. R. Pastusiak, Przedsiębiorstwo na rynku kapitałowym. Operacje giełdowe rynku publicznego i niepublicznego, Warszawa 2010, s. 343-346.

${ }^{4}$ Ibidem, s. 346-347.

${ }^{5}$ Cf. A. Buszko, Przedsiębiorstwo na rynku finansowym. Uwarunkowania analizy strategicznej $w$ okresie globalizacji, Warszawa 2011, s. 184.
} 
wartościowych było rozporządzenie Prezydenta Rzeczpospolitej Polskiej z dnia 28 grudnia 1924 r. o organizacji giełd 6 . Istniały także liczne przepisy wykonawcze ministra skarbu. Zgodnie z zawartymi w nich regulacjami pozwolenia na otwarcie giełd dawał minister skarbu w porozumieniu z ministrem przemysłu i handlu. Z kolei nadzór nad giełdami pieniężnymi sprawował komisarz giełdowy mianowany przez ministra skarbu. Natomiast rząd polski mógł przekazać bezpośredni nadzór nad giełdami „organom handlowym", tzn. izbom handlowym lub korporacjom kupieckim. Warunki działalności maklerów giełdowych w II RP regulowało zaś rozporządzenie ministra skarbu oraz przemysłu i handlu z dnia 25 sierpnia 1921 r. ${ }^{7}$ W 1939 r. wraz z wybuchem II wojny światowej giełda warszawska przestała istnieć. Zostały zamknięte także inne giełdy w kraju. ${ }^{8}$ Po zakończeniu II wojny światowej w 1945 r. podjęto starania zmierzające do przywrócenia giełd finansowych. Były to jednak próby nieudane. Wraz z wprowadzeniem systemu gospodarki nakazowej stało się oczywiste, że istnienie giełdy papierów wartościowych nie ma racji bytu, ponieważ nie pasuje do nowego modelu gospodarki centralnie planowanej ${ }^{9}$. Dopiero w 1989 r. rozpoczęto prace nad budową systemu finansowego obejmującego rynek kapitałowy i giełdę papierów wartościowych.

Pierwszą ważną datą $\mathrm{w}$ historii giełdy papierów wartościowych był 16 października 1990 r. Wtedy to została podpisana umowa między Polską i Francją zakładająca uruchomienie giełdy papierów wartościowych $\mathrm{w}$ Warszawie ${ }^{10}$. W lipcu 1990 r. opracowano pierwszy projekt ustawy regulującej publiczny obrót papierami wartościowymi, a we wrześniu tego samego roku rozpoczęły się prace w Ministerstwie Przekształceń Własnościowych w pionie ds. rozwoju rynku kapitałowego. Pion ten został podzielony na Departament Rozwoju Rynku Kapitałowego, na którego czele stanął Wiesław Rozłucki, oraz na Biuro Komisji Papierów Wartościowych kierowane przez Lesława Pagę. Te dwie komórki dały początek dwóm głównym instytucjom polskiego rynku, czyli Giełdzie Papierów Wartościowych i Komisji Papierów Wartościowych ${ }^{11}$. Dzięki uchwaleniu 22 marca 1991 r. przez Sejm ustawy prawo o

\footnotetext{
${ }^{6}$ Rozporządzenie Prezydenta RP z dnia 28 grudnia 1924 r. o organizacji giełd, Dz. U. z 1924 r. Nr 114 poz. 1020.

7 Rozporządzenie Ministrów Skarbu oraz Przemysłu i Handlu z dnia 25 sierpnia 1921 r. w przedmiocie powoływania i zwalniania oraz praw i obowiązków maklerów na giełdach pieniężnych w Polsce, Dz.U. z 1921r. Nr 83 poz. 586.

8 Cf. P. Kulpaka, Giełdy w gospodarce, Warszawa 2007, s. 121-122.

${ }^{9}$ Cf. System finansowy w Polsce, red. B. Pietrzak, Z. Polański, Warszawa 1997, s. 59.

${ }^{10}$ Cf. K. Jajuga, Podstawy inwestowania na giełdzie papierów wartościowych, Warszawa 2006, s. 96.

11 Cf. U. Ziarko-Siwek, Giełdy kapitałowe w Europie, Warszawa 2007, s. 347.
} 
publicznym obrocie papierami wartościowymi i funduszach powierniczych, Giełda Papierów Wartościowych mogła rozpocząć działalność12.

Kolejnym ważnym wydarzeniem było podpisanie przez ministra przekształceń własnościowych i ministra finansów, reprezentującego Skarb Państwa, aktu założycielskiego spółki akcyjnej Giełda Papierów Wartościowych w Warszawie ${ }^{13}$. Miało to miejsce 12 kwietnia 1991 r., a cztery dni później, tj. 16 kwietnia 1991 r. odbyła się pierwsza sesja giełdowa. Uczestniczyło w niej siedem domów maklerskich. Przedmiotem obrotu były akcje pięciu wcześniej sprywatyzowanych spółek: Exbudu, Kabli, Krosna, Próchnika, Tonsilu. Na tą pierwszą sesję wpłynęło 112 zleceń kupna i sprzedaży, a łączna wartość obrotów wyniosła ok. 2000 USD. Początki polskiego rynku giełdowego były więc niezwykle skromne ${ }^{14}$.

Giełda Papierów Wartościowych została przyjęta jako członek korespondent do Międzynarodowej Federacji Giełd Papierów Wartościowych (FIBV) 3 grudnia 1991 r. Członkiem tej organizacji stała się w październiku 1994 r. Giełda Papierów Wartościowych w Warszawie jest członkiem stowarzyszonym z Europejską Federacją Giełd Papierów Wartościowych od czerwca 1999 r., natomiast jej pełnoprawnym członkiem została w czerwcu 2004 r. Warto zauważyć, że Giełda Papierów Wartościowych w Warszawie jest największą giełdą regionu Europy ŚrodkowoWschodniej, organizuje obrót na jednym z najdynamiczniej rozwijających się rynków kapitałowych w Europie ${ }^{15}$. Ponadto prowadzi rynek regulowany dla akcji oraz instrumentów pochodnych, a także alternatywny rynek akcji NewConnect dla spółek wzrostowych ${ }^{16}$. Co więcej, Giełda rozwija również Catalyst, czyli rynek przeznaczony dla emitentów obligacji korporacyjnych i komunalnych oraz rynek energii ${ }^{17}$. Trzeba również wspomnieć o tym, że sama Giełda Papierów Wartościowych od 9 listopada 2010 r. jest spółką publiczną notowaną na Giełdzie Papierów Wartościowych w Warszawie ${ }^{18}$.

\footnotetext{
12 Cf. A. Buszko, op. cit., s. 185.

13 Cf. U. Banaszczak- Soroka, Instytucje i uczestnicy rynku kapitałowego, Warszawa 2008, s. 103.

14 P. Kulpaka, op. cit., s. 123.

15 Cf. Instytucje parabankowe na rynku usług bankowych w Polsce, red. G. Kotliński, K. Waliszewski, Warszawa 2012, s. 24.

16 R. Pastusiak, op. cit., s. 375-379, Z. Dobosiewicz, Giełda. Zasady działania. Inwestorzy. Rynki giełdowe, Warszawa 2013, s. 177-183.

17 R. Pastusiak, op. cit., s. 379-382, Z. Dobosiewicz, op. cit., s. 160-163.

${ }^{18}$ Cf. K. Oplustil, M. Porzycki, P.M. Woroniecki, Rynek finansowy i kapitałowy [w:] Instytucje gospodarki rynkowej, red. T. Włudyka, M. Smaga, Warszawa 2012, s. 314-315.
} 


\section{Funkcje i rola giełdy papierów wartościowych}

Na wstępie rozważań warto przyjrzeć się doniosłym funkcjom, jakie pełnią giełdy papierów wartościowych ${ }^{19}$. Niezaprzeczalnie efektywne i dobrze funkcjonujące giełdy papierów wartościowych wykonują wiele ważnych zadań w wolnorynkowych gospodarkach państw. Z makroekonomicznego punktu widzenia do najważniejszych funkcji giełd zalicza się funkcje alokacyjne, funkcje wartościujące i funkcje kontrolne20.

Istota funkcji alokacyjnej polega na przepływie kapitału pomiędzy inwestorami instytucjonalnymi, do których zaliczamy towarzystwa ubezpieczeniowe, fundusze emerytalne i fundusze inwestycyjne, a przedsiębiorstwami chcącymi pozyskać kapitał, emitującymi akcje i obligacje. Inwestorzy instytucjonalni wykorzystują do tego środki pieniężne lokowane w nich przez gospodarstwa domowe. Aktywny udział w alokacyjnej funkcji giełdy biorą także inwestorzy indywidualni, którzy mogą inwestować swoje nadwyżki finansowe na rynkach kapitałowych przy pomocy różnorodnych instrumentów. Zwiększająca się liczba uczestników rynku czyni go bardziej konkurencyjnym i zarazem efektywniejszym. Wszystkie grupy inwestorów nabywając instrumenty finansowe, pokrywają koszty działalności gospodarczej przedsiębiorstw i innych podmiotów. Dzięki temu publiczny rynek giełdowy zapewnia emitentom szerszy dostęp do wolnych zasobów kapitałowych.

W gospodarce wolnorynkowej możemy wyróżnić dwa podstawowe sposoby sprawnego i efektywnego przepływu kapitałów od podmiotów dysponujących jego nadwyżkami do tych, które odczuwają jego niedobór. Pierwszy z nich polega na przepływie kapitałów od depozytariuszy, czyli osób deponujących swoje pieniądze w bankach, do kredytobiorców. Drugi natomiast opiera się na bezpośrednim przepływie środków pieniężnych od inwestorów do emitentów poprzez sprawnie funkcjonujące rynki papierów wartościowych. W wielu krajach świata, w tym również w Polsce, obserwuje się działanie i rozwój obu tych mechanizmów. Ich głębsza analiza pozwala zauważyć dość znaczące różnice występujące pomiędzy poszczególnymi państwami. Z

\footnotetext{
${ }^{19}$ Cf. W. Pełka, Rola rynku kapitałowego w gospodarce Polski po akcesji do Unii Europejskiej [w:] Polityka i rozwój gospodarczy Polski w UE ocena i perspektywy, red. S. Pangsy-Kania, G. Szczodrowski, Gdańsk 2005, s. 321-323, M. Daniluk, Rynek kapitałowy. Papiery wartościowe, operacje giełdowe, strategie inwestowania, Warszawa 1998, s. 35-37; A. Kasprzak-Czelej, Giełdowy rynek akcji a gospodarka. Ujęcie funkcyjne, Warszawa 2012, s. 34-47.

${ }^{20}$ Cf. P. Kulpaka, op. cit., s. 51-52.
} 
tego powodu system finansowy można podzielić na systemy: system bankowo zorientowany i system $\mathrm{z}$ dużą rolą rynków papierów wartościowych ${ }^{21}$. W systemie $\mathrm{z}$ dużą rolą rynków papierów wartościowych, oprócz banków występują także rynki finansowe, w tym giełdy papierów wartościowych, które odgrywają znaczącą rolę w alokacji kapitałów. Przepływ ten opiera się na emisji różnorodnych instrumentów finansowych nabywanych na rynku pierwotnym przez inwestorów, a następnie stających się przedmiotem handlu między nimi. Giełda spełnia w tym systemie także funkcję rynku wtórnego. Kapitalizacja tych giełd i liczba notowanych na nich spółek jest bardzo duża. System ten odgrywa ważną rolę w gospodarkach Stanów Zjednoczonych oraz Wielkiej Brytanii. Zależnie od skłonności do ryzyka oraz horyzontu czasowego inwestycji, nadwyżki pieniężne gospodarstw domowych i innych instytucji są inwestowane $\mathrm{w}$ instrumenty rynku pieniężnego i kapitałowego. Niewielka ich część trafia do banków w formie depozytów. Rynki finansowe w większym stopniu niż banki koncentrują się na przyszłości przedsiębiorstw. Banki w dużej mierze interesują się bieżącą sytuacją firmy i zdolnością do spłaty zaciąganych zobowiązań. Natomiast inwestorzy na rynkach kapitałowych bardziej nastawiają się na perspektywy rozwoju danych przedsiębiorstw. Ważne są dla nich przewidywania, że dana spółka przyniesie w przyszłości zyski, nie musi ich generować w obecnej chwili. Dzięki temu spółka ma większe szanse na pozyskanie kapitału ze sprzedaży własnych akcji. Przewagą rynku kapitałowego jest także to, że banki w swojej ocenie przedsiębiorstwa uwzględniają także możliwość przedstawienia odpowiedniego zastawu. W trudnej sytuacji są wówczas postawione spółki innowacyjne, których główne zasoby koncentrują się wokół kapitału ludzkiego i nowych technologii. Dzięki rynkom kapitałowym takie spółki mają możliwość zdobycia kapitału na dalszy rozwój22.

Drugą bardzo istotną funkcją rynków kapitałowych jest funkcja wartościująca, nazywana także funkcją wyceny kapitału. Polega ona na ocenie papierów wartościowych danych spółek, co staje się możliwe dzięki notowaniom papierów wartościowych na sesjach giełdowych. Inwestorzy tworzą popyt i podaż, wystawiając zlecenia na akcje, a transakcje pomiędzy nimi pozwalają ustalić rynkową wycenę spółek ${ }^{23}$.

\footnotetext{
21 Ibidem, s. 52.

22 Cf. A. Sławiński, Rynki Finansowe, Warszawa 2006, s. 12-13.

23 Przedsiębiorstwom, które chcą wyemitować swoje akcje na giełdzie przy pomocy pierwszej oferty publicznej ciężko jest ustalić cenę emisyjną. Może ona bowiem decydować o sukcesie bądź „porażce emitenta”. W przypadku gdy cena rynkowa jest wyższa od ceny emisyjnej, mówi się o „porażce emitenta”,
} 
Trzecią z podstawowych funkcji makroekonomicznych giełd papierów wartościowych jest funkcja kontrolna. Jej podstawowe zadanie sprowadza się do zapewnienia akcjonariuszom spółek skutecznej i efektywnej kontroli nad firmami. Wiąże się to zarówno z powołaniem jak najlepszego kierownictwa przedsiębiorstwa, które przyczyni się w długim okresie do zwiększenia wartości akcji danej firmy, jak i z polityką informacyjną. W znacznie szerszym aspekcie może to przyczynić się do wzrostu efektywności gospodarowania w całej gospodarce, szybszego tempa wzrostu produktu krajowego brutto oraz wyższych dochodów obywateli24.

Giełda papierów wartościowych oprócz wymienionych trzech głównych funkcji, spełnia również szereg innych ważnych zadań. Istnienie giełd pozwala na zwiększanie skłonności do oszczędzania. Gospodarstwa domowe mogą znaleźć odpowiednie dla siebie instrumenty finansowe i lokować w nich swoje oszczędności. Pomnażanie kapitałów przez inwestorów indywidualnych może także wpływać na zwiększenie makroekonomicznej wielkości konsumpcji. Funkcjonowanie giełdy, a zwłaszcza sprawnego rynku pieniężnego umożliwia finansowanie deficytów budżetowych. Jednostki samorządu terytorialnego oraz Skarb Państwa mogą bowiem emitować obligacje, które pomagają pokrywać koszty deficytów tych jednostek, a także obniżają obsługę długu publicznego. Dzieje się tak dzięki zwiększeniu płynności notowanych skarbowych i municypalnych papierów wartościowych. Finansowanie deficytu budżetowego można też uzyskać przez prywatyzację spółek Skarbu Państwa dzięki ofercie publicznej spółek należących do Skarbu Państwa. Środki finansowe pozyskane z takiej oferty trafiają do budżetu państwa. Giełda papierów wartościowych sprzyja także szybszej restrukturyzacji przedsiębiorstw ${ }^{25}$. Pozwala to na wzrost konkurencyjności i efektywności całej gospodarki. W Polsce od 1999 r. można zaobserwować jeszcze jedną dość istotną funkcję giełdy papierów wartościowych, która umożliwiła przeprowadzenie reformy systemu emerytalnego. Fundusze emerytalne mogą lokować na giełdzie środki pieniężne, czyli składki osób pracujących. Bez tego ciężko byłoby znaleźć wystarczającą

\footnotetext{
ponieważ mógł sprzedać swoje akcje drożej, ustalając wyższą ich cenę. W odwrotnym przypadku pojawia się „sukces emitenta”. Sprzedał on bowiem swoje akcje drożej niż wyceniają je inwestorzy na rynku wtórnym. Zysk i sukces spółki może być jednak krótkotrwały i niestabilny. Straty inwestorów mogą skutkować osłabieniem pozycji rynkowej i mniejszym zainteresowaniem podczas kolejnej emisji akcji. Cf. E. Ostrowska, Rynek Kapitałowy, Warszawa 2007, s. 49.

24 Cf. P. Kulpaka, op. cit., s. 57.

25 Cf. A. Kasprzak-Czelej, op. cit., s. 46-47.
} 
ilość płynnych aktywów finansowych, w których Otwarte Fundusze Emerytalne mogłyby inwestować fundusze ${ }^{26}$.

Rolę giełdy w polskiej gospodarce można analizować zarówno $\mathrm{z}$ mikroekonomicznego, jak i makroekonomicznego punktu widzenia ${ }^{27}$. W ujęciu mikroekonomicznym znaczenie rynku giełdowego jest bardzo duże dla poszczególnych osób, firm czy instytucji. Szersze rozumienie roli giełdy, czyli makroekonomiczny aspekt, odnosi się do udziału rynku papierów wartościowych w gospodarce Polski.

W celu odpowiedniego przedstawienia udziału giełdy papierów wartościowych w gospodarce Polski zostały wykorzystane wybrane miary, które zdaniem autorów najwłaściwiej nadają się do opisu obustronnych zależności. Pierwszą z nich jest stosunek kapitalizacji giełdy do wielkości produktu krajowego brutto ${ }^{28}$, przy czym w kapitalizacji giełdy zostały uwzględnione tylko spółki krajowe. Od początku istnienia giełdy stosunek ten systematycznie rośnie, a w 1999 r. przekroczył granicę 20\%, uważaną przez ekspertów za granicę, po przekroczeniu której można zacząć mówić o jakiejkolwiek roli giełdy w gospodarce kraju ${ }^{29}$. Wzrost tego stosunku wiąże się przede wszystkim z prywatyzacjami, które miały miejsce w tymże roku i były przeprowadzone przez publiczny rynek kapitałowy. W kolejnych czterech latach udział kapitalizacji giełdy w PKB utrzymywał się poniżej 20\% za sprawą niekorzystnej koniunktury na warszawskim parkiecie, a także zahamowania ilościowego rozwoju rynku akcji. W 2004 r. nastąpiło już trwałe przekroczenie wcześniej wspomnianej granicy, głównie dzięki powrotowi hossy i dwóm dużym prywatyzacjom. Następne trzy lata to okres niezwykle dynamicznego wzrostu oraz przekroczenia bariery 40\%. W 2008 r. kapitalizacja giełdy zmniejszyła się jednak prawie o 50\%, więc udział w PKB także drastycznie się obniżył. Kolejne lata przyniosły stabilizację udziału kapitalizacji giełdy w PKB na poziomie ok. 30-40\%. Szczegółowe dane zostały zaprezentowane w tabeli 1.

\footnotetext{
${ }^{26}$ Cf. P. Kulpaka, op. cit., s. 63.

$27 \mathrm{Na}$ temat roli polskiej giełdy w pierwszym roku członkostwa Polski w Unii Europejskiej pisze: W. Pełka, op.cit, s. 323-325. Natomiast o wpływie akcesji do Unii Europejskiej na rynek kapitałowy w Polsce szerzej wypowiadają się: B. Ciechanowicz, A. Grzeszuk, Znaczenie instrumentów rynku kapitałowego dla rozwoju gospodarczego Polski w strukturach unijnych [w:] Polityka i rozwój gospodarczy Polski... op. cit., s. 342-343. ${ }^{28}$ Cf. W. Milo, Finansowe rynki kapitałowe, Warszawa 2000, s. 111.

${ }^{29}$ Cf. Projekcja rozwoju rynku kapitałowego do roku 2002, red. E. Pietrzak, Gdańsk 1998, s. 3.
} 
Tabela 1. Relacja kapitalizacji Giełdy Papierów Wartościowych w Warszawie w stosunku do PKB Polski

\begin{tabular}{|c|c|c|c|}
\hline Rok & $\begin{array}{c}\text { Kapitalizacja giełdy } w \\
\text { mln zł }\end{array}$ & $\begin{array}{c}\text { Produkt krajowy brutto w } \\
\text { mln zł }\end{array}$ & $\begin{array}{c}\text { Udział kapitalizacji giełdy } w \\
\text { PKB w proc. }\end{array}$ \\
\hline 1991 & 161 & 80883 & 0,20 \\
\hline 1992 & 351 & 114944 & 0,31 \\
\hline 1993 & 5845 & 155780 & 3,75 \\
\hline 1994 & 7450 & 210407 & 3,54 \\
\hline 1995 & 11271 & 308104 & 3,66 \\
\hline 1996 & 24000 & 358448 & 6,70 \\
\hline 1997 & 43766 & 469327 & 9,33 \\
\hline 1998 & 72442 & 549467 & 13,18 \\
\hline 1999 & 123411 & 615115 & 20,06 \\
\hline 2000 & 130085 & 744378 & 17,48 \\
\hline 2001 & 103370 & 779564 & 13,26 \\
\hline 2002 & 110565 & 808578 & 13,67 \\
\hline 2003 & 140001 & 843156 & 16,60 \\
\hline 2004 & 214313 & 924538 & 23,18 \\
\hline 2005 & 308418 & 983302 & 31,37 \\
\hline 2006 & 437719 & 1060031 & 41,29 \\
\hline 2007 & 509887 & 1176737 & 43,33 \\
\hline 2008 & 267359 & 1275508 & 20,96 \\
\hline 2009 & 421178 & 1344505 & 31,33 \\
\hline 2010 & 542646 & 1416585 & 38,31 \\
\hline 2011 & 446151 & 1528127 & 29,20 \\
\hline 2012 & 523390 & 1595264 & 32,81 \\
\hline 2013 & 593464 & 1635746 & 36,28 \\
\hline
\end{tabular}


Źródło: opracowanie własne na podstawie strony internetowej Giełdy Papierów Wartościowych w Warszawie oraz strony internetowej Głównego Urzędu Statystycznego: <http://www.gpw.pl>, <http://www.stat.gov.pl> [dostęp:29.04.2014].

Ważnym elementem badania roli giełdy papierów wartościowych w gospodarce Polski jest także pokazanie tego, jak zmieniała się liczba notowanych na niej spółek. Analizie zostały poddane tylko spółki krajowe, ponieważ giełda powinna oddziaływać pozytywnie głównie na rodzime przedsiębiorstwa. W 1991 r., czyli na początku istnienia Giełdy Papierów Wartościowych w Warszawie, notowano zaledwie dziewięć spółek. Obecnie ich liczba przekroczyła czterysta. Dynamika wzrostu liczby notowanych spółek krajowych była najwyższa w początkowych latach funkcjonowania warszawskiego parkietu ${ }^{30}$.

Tabela 2. Liczba notowanych spółek na Giełdzie Papierów Wartościowych w Warszawie w latach 1991-2014

\begin{tabular}{|c|c|c|}
\hline Rok & Liczba notowanych spółek & Dynamika zmian w proc. \\
\hline 1991 & 9 & brak \\
\hline 1992 & 16 & 78 \\
\hline 1993 & 22 & 38 \\
\hline 1994 & 44 & 100 \\
\hline 1995 & 65 & 48 \\
\hline 1996 & 83 & 28 \\
\hline 1997 & 143 & 38 \\
\hline 1998 & 2168 & -6 \\
\hline 1999 & 221 & 2 \\
\hline 2000 & 230 & 2 \\
\hline 2001 & & \\
\hline 2002 & & \\
\hline 2003 & 202 & \\
\hline
\end{tabular}

${ }^{30}$ Cf. W. Nawrot, Perspektywy rozwoju rynku papierów wartościowych w Polsce na tle Strategii Lizbońskiej [w:] Polityka i rozwój gospodarczy Polski... op. cit., s. 350-351. 


\begin{tabular}{|l|c|c|}
\hline 2004 & 225 & 11 \\
\hline 2005 & 248 & 10 \\
\hline 2006 & 272 & 21 \\
\hline 2007 & 328 & 6 \\
\hline 2008 & 349 & 1 \\
\hline 2009 & 354 & 5 \\
\hline 2010 & 373 & 4 \\
\hline 2011 & 387 & 2 \\
\hline 2012 & 395 & 0 \\
\hline 2013 & 403 & \\
\hline 2014 & & \\
\hline
\end{tabular}

Źródło: opracowanie własne na podstawie strony internetowej Giełdy Papierów Wartościowych w Warszawie: <http://www.gpw.pl> [dostęp: 29.04.2014].

Z przedstawionej powyżej analizy wynika, że liczba notowanych spółek ustabilizowała się i nie zwiększa się już tak dynamicznie jak w początkowych latach funkcjonowania Giełdy Papierów Wartościowych w Warszawie. Przyczyną takiego stanu rzeczy są z pewnością większe trudności w pozyskiwaniu kapitału związane z trwającą w latach 2007-2009 bessą, która zmniejszyła zainteresowanie inwestorów ofertami publicznymi ${ }^{31}$. Drugim istotnym czynnikiem jest utworzony w 2007 r. przez Giełdę Papierów Wartościowych w Warszawie alternatywny rynek NewConnect ${ }^{32}$, na którym notuje się obecnie blisko czterysta pięćdziesiąt podmiotów. Wiele spółek wybrało właśnie ten rynek, bowiem wprowadzenie akcji do obrotu było tam znacznie łatwiejsze ze względu na dużo niższe kryteria oraz koszty. Wejście na rynek NewConnect nie wymaga kapitalizacji spółki na poziomie 15 mln EUR oraz przeprowadzenia oferty publicznej, w tym także sporządzenia prospektu emisyjnego ${ }^{33}$.

\footnotetext{
31 Cf. Z. Dobosiewicz, op. cit., s. 145-146.

32 Cf. U. Banaszczak-Soroka, op. cit., s. 120-121.

33 Szerzej na temat przyczyn zainteresowania spółek rynkiem NewConnect: Z. Dobosiewicz, op. cit., s. 177-181.
} 


\section{Giełda papierów wartościowych a parametry makroekonomiczne}

Giełda papierów wartościowych jest jedną z głównych części rynku finansowego. Rynek finansowy stanowi z kolei bardzo ważną część gospodarki kraju. Między rynkiem finansowym a jego otoczeniem występują pewne współzależności, szczególnie między giełdą a gospodarką ${ }^{34}$. Owe zależności są dwustronne, co oznacza, że zarówno rynek finansowy oddziałuje na gospodarkę, jak i gospodarka wpływa na rynek finansowy. Z jednej strony dobrze funkcjonujący rynek finansowy wywiera nacisk na gospodarkę, prowadząc do tego, że dzięki niemu środki pieniężne trafiają do tych przedsiębiorstw, w których są one efektywnie alokowane. To z kolei powoduje zwiększenie się produktu krajowego brutto. Z drugiej zaś strony gospodarka znacząco wpływa na rynek finansowy. Łatwo dostrzec ważne zależności pomiędzy napływającymi informacjami gospodarczymi a podejmowanymi przez inwestorów decyzjami inwestycyjnymi ${ }^{35}$. W tym kontekście warto wspomnieć o tzw. hipotezie efektywności informacyjnej rynku akcji. Efektywny informacyjnie rynek kapitałowy jest takim rynkiem, na którym ceny instrumentów finansowych $\mathrm{w}$ pełni odzwierciedlają wszystkie informacje, które powinny na nie oddziaływać ${ }^{36}$. W związku z tym wyróżnia się pewne podzbiory informacji i mówi się o efektywności względem nich ${ }^{37}$.

Bardzo ważny wpływ na rynek akcji i obligacji ma stopa procentowa ${ }^{38}$. Jednak zależność wpływu stopy procentowej na ceny akcji nie będzie już tak oczywista jak w przypadku rynku obligacji. Wydaje się, że ceny akcji powinny rosnąć, jeżeli stopa procentowa spada, a obniżać się przy jej wzroście. Działa tutaj ten sam mechanizm co w przypadku obligacji i pojawiania się nowych bardziej lub mniej atrakcyjnych form

\footnotetext{
${ }^{34}$ Cf. W. Milo, op. cit., s. 108 i nn.

${ }^{35}$ Cf. K. Jajuga, op. cit., s. 125-126.

36 Cf. J. Czekaj, Rynki, instrumenty i instytucje finansowe, Warszawa 2008, s. 412, H. Gurgul, Analiza zdarzeń na rynkach akcji. Wpływ informacji na ceny papierów wartościowych, Kraków 2006, s. 19-21.

${ }^{37}$ W tym kontekście można wyróżnić: 1) słabą efektywność rynku rozumianą jako sytuację, w której ceny instrumentów finansowych natychmiastowo i w pełni odzwierciedlają informacje zawarte w historycznych notowaniach tych instrumentów; 2) półsilną efektywność rynku rozumianą jako sytuację, w której ceny instrumentów finansowych natychmiastowo i prawidłowo odzwierciedlają informacje zawarte nie tylko $\mathrm{w}$ notowaniach historycznych, ale również wszystkie inne publicznie dostępne informacje; 3) silną efektywność rynku rozumianą jako sytuację, gdy w cenach instrumentów finansowych bez żadnego opóźnienia są zawarte wszystkie informacje dostępne publicznie i prywatnie. Cf. J. Czekaj, op. cit., s. 413.

${ }^{38}$ Istnieje prosta zależność: przy wzroście stóp procentowych spada cena obligacji, a przy spadku stóp procentowych wzrasta cena obligacji. W odniesieniu do obligacji wynika to $\mathrm{z}$ tego, iż jest to instrument, $\mathrm{w}$ którym znane są dochody, które będą uzyskane w przyszłości. Wzrost stóp procentowych powoduje wystąpienie alternatywnych form inwestowania, a więc cena obligacji spadnie. Spadek stóp procentowych sprawia, że pojawią się mniej atrakcyjne formy inwestowania, zatem cena obligacji wzrośnie.
} 
inwestowania. Warto jednak zwrócić uwagę na to, że akcje i obligacje są wobec siebie konkurencyjnymi formami alokowania nadwyżek finansowych. Oznacza to, że w przypadku podniesienia się stopy procentowej i spadku cen obligacji, ceny akcji mogą wzrosnąć, natomiast obniżeniu się stopy procentowej i wzrostowi cen obligacji może towarzyszyć spadek cen akcji ${ }^{39}$.

Czynnikiem wpływającym na sytuację na rynkach kapitałowych jest także kurs walutowy. W Polsce obowiązuje płynny system kursów walutowych. Kursy walut są publikowane przez Narodowy Bank Polski. Ogólne zależności pomiędzy kursem obcej waluty a rynkiem finansowym obejmują: 1) wzrost kursu walutowego (aprecjacja obcej waluty), który powoduje spadek atrakcyjności inwestycji w danym kraju; 2) spadek kursu walutowego (deprecjacja obcej waluty), który doprowadza do wzrostu atrakcyjności inwestycji w danym kraju ${ }^{40}$.

Duże znaczenie dla rynków finansowych ma ponadto inflacja i produkt krajowy brutto. Inflacja wpływa bowiem na zmiany stóp procentowych w gospodarce. Wzrost bądź spadek stopy inflacji oznacza wzrost lub spadek stóp procentowych, a więc wywołuje takie same efekty. Dodatkowo, zmiana stopy inflacji oddziałuje na zmiany realnego dochodu osiąganego $\mathrm{z}$ inwestycji na rynku finansowym, a to przecież on jest głównym przedmiotem zainteresowania inwestora. Wzrost albo spadek stopy inflacji wskazuje na spadek albo wzrost realnej stopy dochodu. Relacje między produktem krajowym brutto a rynkiem finansowym są dwustronne. Szybki wzrost PKB oddziałuje korzystnie na rynek finansowy ${ }^{41}$. Świadczy to o dobrej sytuacji gospodarczej, wzroście produkcji oraz zwiększeniu oszczędności inwestycji. Wzmaga się także zainteresowanie podmiotów rynkiem finansowym, które powoduje zwiększenie obrotów na rynku i dochodów tych podmiotów. Natomiast sytuacja na rynku finansowym wpływa na produkt krajowy brutto. Chodzi tu głównie o rynek kasowy, ponieważ szybko reaguje on

\footnotetext{
${ }^{39}$ Cf. K. Jajuga, op. cit., s. 114-115.

40 Dla lepszego zobrazowania wyżej wymienionych zależności warto posłużyć się przykładem. Przyjmiemy tutaj kurs euro wyrażony w polskich złotych. W przypadku gdy kurs ten wzrasta w Polsce, dla inwestora europejskiego jest to aprecjacja waluty, zmniejsza się jego dochód. Inwestycje w Polsce stają się wówczas dla niego mniej atrakcyjne. Jednak w dłuższej perspektywie czasowej może nastąpić poprawa sytuacji polskich przedsiębiorstw, które dzięki wyższemu kursowi będą mogły więcej eksportować do krajów strefy euro. Poprawa ta powinna się w związku z tym przyczynić do lepszych wyników polskich spółek, a więc do wzrostu ich wartości oraz kursu na giełdzie. W odwrotnym przypadku, czyli spadku kursu euro względem polskich złotych, zwiększa się dochód inwestora europejskiego lokującego na polskim rynku kapitałowym. Jednak w długim okresie niski kurs euro może doprowadzić do spadku eksportu polskich przedsiębiorstw do krajów strefy euro, co w konsekwencji może pogorszyć ich sytuację gospodarczą, a także obniżyć cenę ich akcji na Giełdzie Papierów Wartościowych.

41 Cf. Z. Dobosiewicz, op. cit., Warszawa 2013, s. 68-69.
} 
na poprawę kondycji finansowej emitentów. Istnieje również przekonanie, że procesy zachodzące na rynku akcji „wyprzedzają” procesy przebiegające w całej gospodarce, których efektem będzie szybszy bądź wolniejszy wzrost PKB.

\section{Interakcje pomiędzy giełdą papierów wartościowych a gospodarką kraju}

Ceny notowanych na giełdzie instrumentów finansowych w średnim i długim okresie zachowują się procyklicznie. W krajach z gospodarką rynkową i rozwiniętą giełdą papierów wartościowych istnieje kilka mechanizmów zapewniających obustronne związki koniunktury giełdowej z gospodarczą. Oddziaływanie giełdy na gospodarkę może powodować efekty względnych zmian ceny kapitału oraz efekty dochodowe. Wzrost cen papierów wartościowych przyczynia się do obniżenia ceny pozyskania kapitału na giełdzie, ponieważ dobra koniunktura giełdowa sprzyja emitentom podczas emisji na rynku pierwotnym. To z kolei wpływa na zwiększenie inwestycji spółek, a tym samym na poprawę koniunktury gospodarczej. Zależność ta działa również w odwrotną stronę, czyli pogorszenie się sytuacji na giełdzie, negatywnie wpływa na koniunkturę gospodarczą z powodu zwiększenia się ceny pozyskania kapitału, co zaś pociąga za sobą zmniejszenie inwestycji. Szybszy wzrost gospodarczy wiąże się także z wiarygodnością kredytową spółek. Wzrost wartości akcji przyczynia się do wyższej oceny zdolności kredytowej kredytobiorców, a zatem może stymulować nasilenie się inwestycji, a to w dłuższej perspektywie mogłoby korzystnie wpłynąć na tempo wzrostu gospodarczego. Trzecim aspektem zmian cen kapitału są tzw. „samosprawdzające się prognozy”. Ich istota polega na tym, że inwestorzy przewidując ożywienie gospodarcze, zwiększają poziom dokonywanych inwestycji, ponieważ liczą na wyższą stopę zwrotu $\mathrm{z}$ zainwestowanych kapitałów ${ }^{42}$. Przyjmuje się, że poziom indeksu giełdowego jest wskaźnikiem, który wyprzedza zmiany koniunktury giełdowej, a więc wzrost cen akcji staje się sygnałem, że w gospodarce można liczyć na ożywienie ${ }^{43}$.

Giełda oddziałuje na gospodarkę także za pomocą efektu dochodowego. Składają się na niego przyrost gromadzonych aktywów oraz wzrost oczekiwanych dochodów.

\footnotetext{
42 Cf. J. Fundowicz, B. Wyżnikiewicz, Fluktuacje koniunktury gospodarczej i giełdowej - perspektywa makroekonomiczna [w:] Diagnozowanie i prognozowanie koniunktury gospodarczej w Polsce, red. M. Mocek, Poznań 2006, s. 2-3.

43 Cf. J. Fundowicz, Koniunktura giełdowa a koniunktura makroekonomiczna [w:] Diagnozowanie koniunktury gospodarczej w Polsce, red. K. Piech, S. Pangsy-Kania, Warszawa 2003 s. 144.
} 
Przyrost gromadzonych aktywów polega na tym, że wzrost wartości instrumentów finansowych notowanych na giełdzie powoduje zwiększenie się wartości zasobów zgromadzonych przez gospodarstwa domowe. Zwiększenie się zasobów może prowadzić do wzrostu konsumpcji, a jego siła będzie wówczas uzależniona od udziału w aktywach gospodarstw domowych instrumentów giełdowych. Wzrost oczekiwanych dochodów oznacza, że zwiększenie się cen akcji obrazuje lepszą kondycję finansową przedsiębiorstw, co może pociągnąć za sobą wyższą dywidendę oraz wyższe wynagrodzenia pracowników. Według teorii cyklu życia konsumpcja jest funkcją dochodów gospodarstw domowych w ciągu całego okresu ich istnienia, więc wzrost cen akcji przyczyni się do przyszłego wzrostu tak dochodu, jak i poziomu bieżącej konsumpcji ${ }^{44}$.

W związku z łączeniem koniunktury na giełdzie ze zmianami dynamiki głównych elementów produktu krajowego brutto wyróżnia się trzy kanały oddziaływania: 1) efekt konsumpcyjny; 2) efekt inwestycyjny oraz 3) efekt kredytowy45. Pierwszy z nich został już po części przybliżony w powyższych rozważaniach. Hossa na rynku akcji powoduje zwiększenie się aktywów gospodarstw domowych, natomiast bessa prowadzi do ich zmniejszenia. W tego efekcie korzystna koniunktura na giełdzie przyczynia się do wzrostu konsumpcji prywatnej, a niekorzystna do jej spadku. Efekt inwestycyjny wiąże się natomiast z nastrojami inwestorów. Hossa na rynku papierów wartościowych wywołuje pozytywne nastroje jego uczestników, a to z kolei wzmacnia chęć zakupu papierów wartościowych nie tylko na rynku wtórnym, ale i pierwotnym. Dzięki temu emitenci mogą pozyskać kapitał na korzystniejszych warunkach i przeznaczyć go na zaplanowane inwestycje. Efekt kredytowy zakłada zależność pomiędzy rynkiem kapitałowym a rynkiem bankowym. Koniunktura giełdowa wpływa na możliwości przedsiębiorstw w zakresie pozyskiwania kapitału przez kredyty bankowe. Podczas hossy wartość akcji wzrasta, a więc spółka staje się bardziej wiarygodna dla banku i może wynegocjować lepsze warunki udzielenia kredytu ${ }^{46}$.

W związku z przeprowadzoną analizą odnoszącą się do roli i wpływu giełdy na gospodarkę kraju warto w tym miejscu zwrócić również uwagę na mechanizmy

\footnotetext{
${ }^{44}$ Cf. J. Fundowicz, B. Wyżnikiewicz, op. cit., s. 4.

45 Cf. E. Łon, Makroekonomiczne uwarunkowania koniunktury na polskim ryku akcji w świetle doświadczeń międzynarodowych, Poznań 2006, s. 23.

${ }^{46}$ Cf. W. Nawrot, Rynek kapitałowy i jego rozwój, Warszawa 2008, s. 65-66.
} 
oddziaływania gospodarki na giełdę. Niewątpliwie ich rola jest znacząca. Zasadniczo, podział obejmuje reakcje inwestorów oraz politykę makroekonomiczną. W pierwszym przypadku chodzi o reakcje na wyniki spółek oraz na dane makroekonomiczne. Informacje o zwiększonych zyskach spółek wpływają pozytywnie na ich wycenę oraz wartość indeksów giełdowych. Pozytywnie na wycenę oddziałują także dobre informacje makroekonomiczne płynące z gospodarki, ponieważ poprawa koniunktury gospodarczej może umożliwić przedsiębiorstwom szybszy rozwój oraz poszerzyć rynki zbytu. Ważną grupą mechanizmów oddziałujących na gospodarkę jest ponadto polityka gospodarcza państwa, w skład której wchodzą: polityka fiskalna, polityka monetarna oraz polityka strukturalna. Jednym z przykładów może być obniżenie podatku nakładanego na przedsiębiorców, co wpłynie na wzrost cen akcji, ponieważ więcej wypracowanego zysku pozostanie w przedsiębiorstwach. Jeśli chodzi politykę strukturalną, to można wyliczać wiele przykładów jej oddziaływania na ceny notowanych instrumentów finansowych. Ogłoszenie informacji o rządowym programie rozwoju budownictwa mieszkaniowego, rozwoju infrastruktury kolejowej lub drogowej wpłynie pozytywnie na wyceny akcji spółek $\mathrm{z}$ sektora budowlanego oraz deweloperskiego ${ }^{47}$.

Warto empirycznie zweryfikować istnienie powiązań pomiędzy rynkiem papierów wartościowych a gospodarką kraju. Aby porównać koniunkturę giełdową z koniunkturą gospodarczą należy zestawić ze sobą wskaźniki, które służą wyznaczaniu obu koniunktur. Najprostszym barometrem określającym sytuację panującą na giełdzie papierów wartościowych jest indeks giełdowy. Natomiast do pomiaru sytuacji w gospodarce używa się zazwyczaj produktu krajowego brutto. Różnice w pomiarach obu wskaźników zaprezentowano w tabeli 3.

Tabela 3. Różnice w pomiarze PKB i indeksów giełdowych

\begin{tabular}{|c|l|l|}
\hline & \multicolumn{1}{|c|}{ Wskaźniki PKB } & \multicolumn{1}{c|}{ Indeksy giełdowe } \\
\hline Częstotliwość pomiaru & raz na kwartał & $\begin{array}{l}\text { codziennie (dni, w których } \\
\text { odbywa się sesja giełdowa) }\end{array}$ \\
\hline Moment publikacji & 10 tygodni po kwartale & ciągły codzienny \\
\hline
\end{tabular}

${ }^{47}$ Cf. J. Fundowicz, B. Wyżnikiewicz, op. cit., s. 5-6. 


\begin{tabular}{|c|l|l|}
\hline Weryfikacja pomiaru & $\begin{array}{l}\text { kolejne przybliżenia szacunku; } \\
\text { rewizje danych historycznych }\end{array}$ & brak \\
\hline Punkt odniesienia & $\begin{array}{l}\text { analogiczny kwartał roku } \\
\text { poprzedniego; poprzedni } \\
\text { kwartał }\end{array}$ & $\begin{array}{l}\text { dzień poprzedni lub inny } \\
\text { dowolny dzień }\end{array}$ \\
\hline
\end{tabular}

Źródło: Opracowanie własne na podstawie J. Fundowicz, B. Wyżnikiewicz, Fluktuacje koniunktury gospodarczej $i$ giełdowej - perspektywa makroekonomiczna [w:] Diagnozowanie i prognozowanie koniunktury gospodarczej w Polsce, red. M. Mocek, Poznań 2006, s. 9.

Analiza opiera się na kwartalnych obliczaniach tempa zmiany średnich wartości indeksów w porównaniu $\mathrm{z}$ analogicznym kwartałem roku poprzedniego. Tak przygotowane szeregi zestawiono z szeregami kwartalnego tempa wzrostu produktu krajowego brutto, również w porównaniu z analogicznymi kwartałami lat poprzednich. W Polsce analiza ta objęła lata 1995-2004. W 1995 r. nie stwierdzono zależności korelacyjnej, ale może to wynikać przede wszystkim z tego, iż była to początkowa faza rozwoju jeszcze niedojrzałego polskiego rynku kapitałowego. Jednak od 1996 r. widać wyraźnie, że indeks WIG zaczął się zachowywać jak makroekonomiczny wskaźnik PKB. Wartość współczynnika korelacji w analizowanych szeregach wyniosła w okresie od pierwszego kwartału 1996 r. do czwartego kwartału 2004 r. ponad 0,73, a to prowadzi do konstatacji, że giełda jest dość mocno skorelowana z gospodarką ${ }^{48}$.

Do interesujących wniosków prowadzi porównanie cyklu giełdowego z cyklem gospodarczym, co przedstawia rysunek 1. Zaprezentowano na nim relacje między rynkami finansowymi a gospodarką w ujęciu cykliczności. Obrazuje on, że cykl giełdowy wyprzedza cykl gospodarczy o 3-9 miesięcy. Na początku wzrostu na giełdzie zyskują spółki finansowe i dobra konsumpcyjne. W dalszej kolejności zyski osiągają spółki technologiczne, przemysłowe i transportowe. Przed końcem szczytu giełdowego zaczynają tracić obligacje oraz spółki z sektora energetycznego. Natomiast po szczycie giełdowym najmocniej tracą akcje spółek usługowych oraz usług użyteczności publicznej. Następnie zaczynają zyskiwać obligacje oraz spółki sektora finansowego. Ciekawym zjawiskiem jest to, że najpierw zaczynają generować zyski obligacje, a dopiero potem akcje. Może to oznaczać, że w końcowej fazie spadku w gospodarce, inwestorzy chętniej alokują swoje zasoby finansowe w bezpieczniejszych

\footnotetext{
48 Ibidem, s. 5-6.
} 
instrumentach, a dopiero potem starają się lokować w instrumenty o wyższym ryzyku inwestycyjnym ${ }^{49}$.

Rysunek 1. Cykl giełdowy a cykl gospodarczy

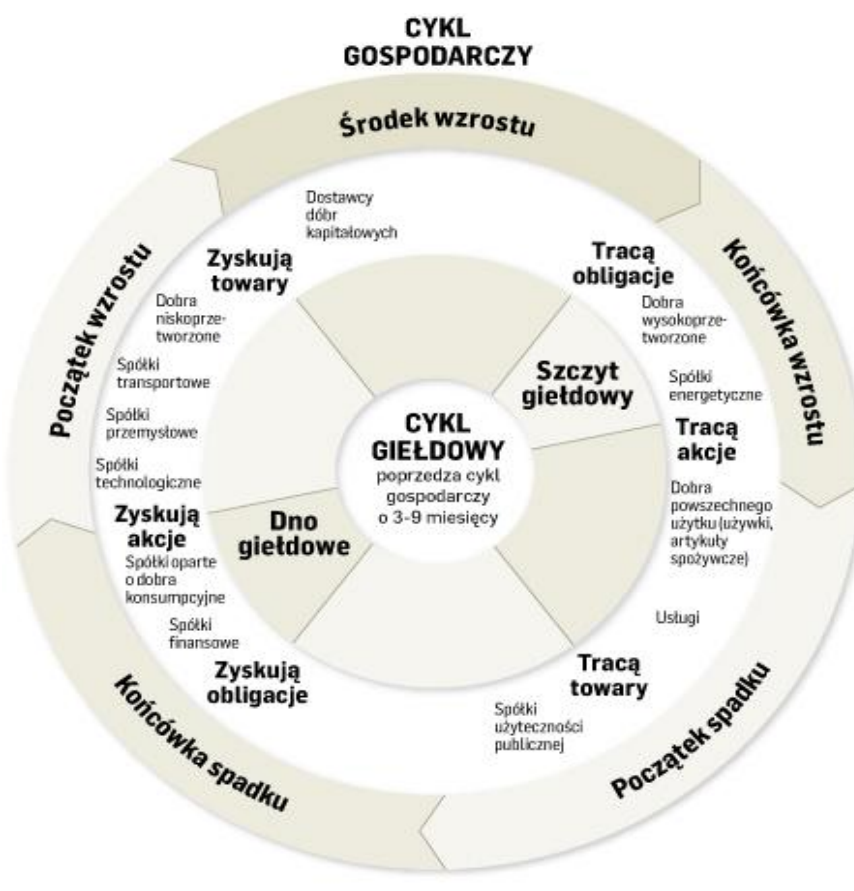

Źródło: Strona internetowa Pulsu Biznesu <http://www.pb.pl> [dostęp: 29.04.2014].

Ostatnie badania wykorzystujące zaawansowane metody ekonometryczne pozwalają na wysunięcie kilku ciekawych wniosków50:

1. Istnieje dwukierunkowa zależność pomiędzy rozwojem sektora finansowego a wzrostem gospodarczym.

2. Wpływ rozwoju sektora finansowego na wzrost gospodarczy jest bardziej istotny w przypadku państw rozwijających się.

3. Im dłuższy jest okres próby, tym większe jest oddziaływanie rozwoju sektora finansowego na wzrost, co oznacza, że całkowity wpływ rozciąga się w czasie.

4. W długich okresach wpływ tego wzrostu na rozwój sektora finansowego staje się nieistotny, nawet jeśli chodzi o państwa wysoko rozwinięte gospodarczo.

\footnotetext{
${ }^{49}$ Cf. także M. Daniluk, op. cit., s. 153-155.

${ }^{50}$ Cf. W. Milo, G. Szafrański, Z. Wośko, M. Malczewski, Rynki inwestycyjne a wzrost gospodarczy, Łódź 2006, s. 138.
} 


\section{Rozwój Giełdy Papierów Wartościowych w Warszawie i jego uwarunkowania}

Rozwój rynku kapitałowego, w tym m.in. Giełdy Papierów Wartościowych w Warszawie ma ogromne znaczenia dla zwiększania jej roli w gospodarce Polski. Z tego też powodu warto przeanalizować przebieg zmian zachodzących na polskim rynku kapitałowym.

W związku z tym należy spojrzeć na rozwój rynku giełdowego w Polsce pod kątem zmiany wartości akcji. W tym celu należy posłużyć się indeksem giełdowym WIG, który jest najlepszym barometrem obrazującym sytuację na rynku. Wartość indeksu WIG na przestrzeni lat została pokazana na wykresie 1.

Wykres 1. Wartość indeksu WIG na koniec roku w latach 1991-2014

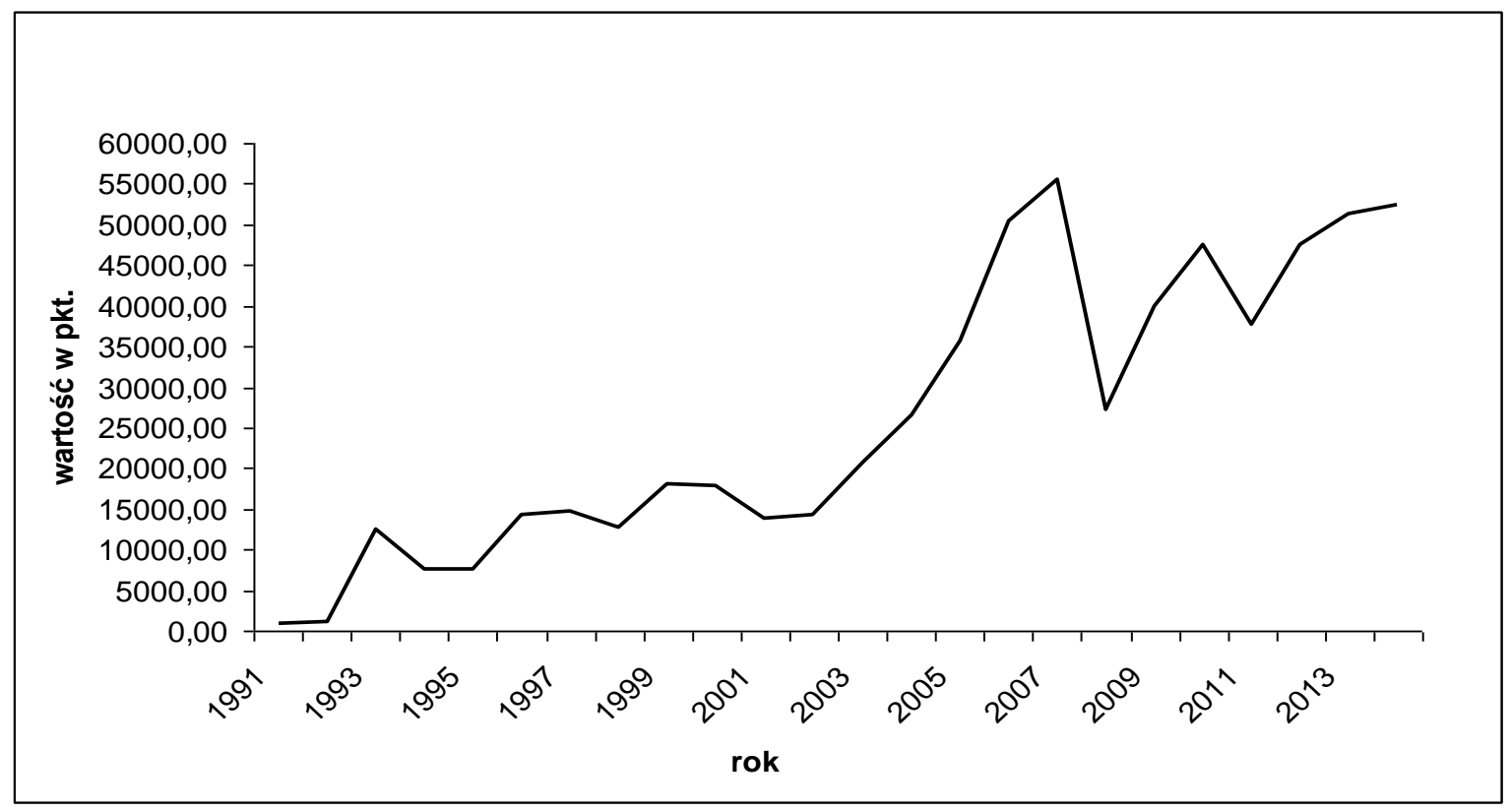

Źródło: opracowanie własne na podstawie strony internetowej Giełdy Papierów Wartościowych w Warszawie <http://www.gpw.pl> [ dostęp: 29.04.2014].

Wartość początkowa indeksu WIG wynosiła 1000 pkt i została ustalona podczas pierwszej sesji giełdowej w 1991 r. Pierwsze dwa lata funkcjonowania giełdy to okres bessy. Kolejny rok, 1993, zakończył się prawie 1200\% wzrostem w stosunku do roku poprzedniego, ale wzrost ten znacząco zmalał w następnym roku. W ciągu następnych 
lat indeks wahał się na dość niskim poziomie. Dopiero od 1996 r. można mówić o powrocie lepszej koniunktury, która pozwoliła na wzrost WIG-u do poziomu 17000 pkt. W kolejnych latach pojawiły się kryzysy, najpierw w państwach azjatyckich, następnie w Rosji. Przyczyniły się one do spadku cen akcji na polskiej Giełdzie Papierów Wartościowych. Na przełomie 1999 i 2000 r. zakończyła się ogólnoświatowa hossa internetowa, która oddziaływała także na polski rynek kapitałowy, doprowadzając ceny wielu walorów do rekordowych poziomów. W następnych latach miała jednak miejsce korekta na polskim parkiecie. Ta słaba koniunktura utrzymała się do połowy $2003 \mathrm{r}$. Wtedy nastąpiła poprawa sytuacji, która z czasem przerodziła się w hossę giełdową. Indeks WIG bił kolejne rekordy, ustanawiając w lipcu 2007 r. szczytowy wynik - 67 772,91 pkt. Później pojawiła się jednak bessa, która sprawiła, że indeks spadł w 2009 r. do poziomu 20000 pkt WIG osiągnął dno i rozpoczął dynamiczne odbicie, przebijając kolejne poziomy i dochodząc do 50000 pkt w kwietniu 2011 r. Niestety problemy związane z finansami publicznymi krajów Unii Europejskiej doprowadziły wówczas do blisko 30\% przeceny na rynkach akcji. Od połowy 2012 r. indeks WIG znajduje się w trendzie wzrostowym i jego wartość przekracza poziom 50000 pkt.

Uwarunkowania rozwoju rynku kapitałowego w Polsce można podzielić na makroekonomiczne i instytucjonalne. W skali makroekonomicznej na rynek kapitałowy w Polsce mają wpływ trzy podstawowe grupy czynników ${ }^{51}$ :

1. kształtowanie się podstawowych wskaźników ekonomicznych w polskiej gospodarce. Szczególne znaczenie ma w tym względzie wiarygodna polityka fiskalnomonetarna;

2. sytuacja na wiodących rynkach zagranicznych, będąca pochodną sytuacji ekonomicznej. Z punktu widzenia polskiego rynku istotna jest sytuacja na rynku amerykańskim oraz na rynku Unii Europejskiej. Została stwierdzona silna korelacja pomiędzy NASDAQ a WIG;

3. generowanie zysków przez spółki giełdowe. Ich brak powoduje obniżenie się atrakcyjności inwestowania w sektor akcji na rzecz sektora papierów skarbowych.

Uwarunkowania instytucjonalne dzielą się na stronę podażową i popytową. Po stronie podażowej największym problemem stało się zatrzymanie w pierwszych latach

${ }^{51}$ Cf. M. Dusza, Rynek kapitałowy w Polsce [w:] B. Pietrzak, Z. Polański, B. Woźniak, System Finansowy w Polsce, Warszawa 2008, s. 304-305. 
obecnego stulecia wzrostu kapitalizacji Giełdy Papierów Wartościowych w Warszawie. Głównymi przyczynami takiego stanu rzeczy były: kończenie się etapu dużych prywatyzacji przedsiębiorstw państwowych, wycofywanie z rynku spółek przejętych przez inwestorów strategicznych oraz niekorzystny wpływ dekoniunktury giełdowej. Dobra koniunktura giełdowa w latach 2004-2005 oraz ożywienie gospodarcze zmieniły tę sytuację - nastąpił wzrost liczby notowanych spółek oraz znacząco wzrosła kapitalizacja. Obecnie przyjmuje się, że jedynie sektor prywatny może przyczynić się do znaczącego zwiększenia podaży nowych akcji na rynku, dlatego warto zwrócić uwagę właśnie na ten sektor w rozwoju rynku. Po stronie popytowej znacząco rozbudowywał się segment inwestorów instytucjonalnych. Stało się tak przede wszystkim za sprawą silnego rozwoju funduszy emerytalnych, stale zasilanych środkami finansowymi, oraz funduszy inwestycyjnych, które stanowią jeden z najważniejszych elementów całego systemu. Wartość aktywów netto Otwartych Funduszy Emerytalnych na koniec 2005 r. wynosiła 86,1 mld zł, natomiast na koniec czerwca 2007 r. już 138,9 mld zł. To wzrost o ponad $50 \%$.

Ostatnie lata to okres dynamicznego wzrostu liczby inwestorów indywidualnych, którzy posiadają rachunki inwestycyjne (zob. tabela 4). Wynika to zapewne z przeprowadzenia kilku znaczących IPO (ang. Initial Public Offer — Pierwsza oferta publiczna) przez spółki należące do Skarbu Państwa. Należy tutaj wymienić m.in. PZU S.A., Tauron Polska Energia S.A., GPW S.A., JSW S.A., Energa S.A. oraz PKP Cargo S.A. ${ }^{52}$. Świadczy to o zwiększeniu się zainteresowania inwestorów indywidualnymi możliwościami lokowania nadwyżek kapitałowych $\mathrm{w}$ inne instrumenty niż lokaty bankowe. Po raz pierwszy bariera miliona rachunków inwestycyjnych została przekroczona w 1997 r. Na uwagę zasługuje także to, że okres giełdowej hossy w latach 2003-2007 nie przyniósł praktycznie w ogóle wzrostu liczby otwartych rachunków maklerskich. Dopiero zapoczątkowane w 2010 r. prywatyzacje ogromnych spółek państwowych znacząco powiększyły grono inwestorów w Polsce.

Tabela 4. Liczba rachunków inwestycyjnych w Polsce w latach 1991-2014

\begin{tabular}{|l|l}
\hline Rok & Liczba rachunków inwestycyjnych \\
\hline
\end{tabular}

\footnotetext{
${ }^{52}$ Cf. <http://www.akcjonariatobywatelski.pl/pl/debiuty-gieldowe> [dostęp: 29.04.2014].
} 


\begin{tabular}{|c|c|}
\hline 1991 & 54 \\
\hline 1992 & 76 \\
\hline 1993 & 281 \\
\hline 1994 & 831 \\
\hline 1995 & 808 \\
\hline 1996 & 894 \\
\hline 1997 & 1181 \\
\hline 1998 & 1262 \\
\hline 1999 & 1158 \\
\hline 2000 & 1236 \\
\hline 2001 & 1085 \\
\hline 2002 & 1016 \\
\hline 2003 & 947 \\
\hline 2004 & 851 \\
\hline 2005 & 853 \\
\hline 2006 & 909 \\
\hline 2007 & 997 \\
\hline 2008 & 1029 \\
\hline 2009 & 1133 \\
\hline 2010 & 1477 \\
\hline 2011 & 1498 \\
\hline 2012 & 1509 \\
\hline 2013 & 1495 \\
\hline
\end{tabular}

Źródło: opracowanie własne na podstawie strony internetowej Giełdy Papierów Wartościowych w Warszawie (data dostępu: 29.04.2014 r.)

\section{Perspektywy rozwoju Giełdy Papierów Wartościowych w Warszawie}

Na początku 2014 r. Giełda Papierów Wartościowych w Warszawie przedstawiła strategię rozwoju o nazwie „GPW.2020”. Jej strategicznym celem jest odgrywanie - 
samodzielnie albo z dużym podmiotem branżowym - dominującej roli w regionie Europy Środkowo-Wschodniej oraz zdobycie znaczącej pozycji na europejskim rynku kapitałowym. Strategia Giełdy została oparta na dwóch podstawowych założeniach. Pierwsze z nich zakłada maksymalizację wykorzystania dotychczasowych źródeł wzrostu Grupy Kapitałowej ze szczególnym uwzględnieniem potencjału lokalnej bazy inwestorów i emitentów. Drugim filarem rozwoju ma być natomiast pogłębiona dywersyfikacja źródeł przychodów i umiędzynarodowienie działalności53.

Jednym z kluczowych działań, które mają się przyczynić do realizacji celu strategicznego, będzie wspieranie polskiej gospodarki, w tym również polskiego rynku kapitałowego oraz gospodarek naszego regionu, poprzez świadczenie usług finansowych charakteryzujących się bardzo wysoką jakością. Giełda Papierów Wartościowych ma także plany zbudowania w Warszawie międzynarodowego centrum finansowego oraz podjęcia aktywności w obszarze ciągłego podnoszenia zaufania do rynku kapitałowego.

Giełda zamierza eksploatować te z dotychczasowych źródeł wzrostu, które nie zostały jeszcze wykorzystane w optymalnym stopniu. Zaliczyć tu można m.in. płynność obrotu notowanych instrumentów, skłonność gospodarstw domowych do inwestycji giełdowych, strukturę finansowania rozwoju przedsiębiorstw prywatnych i samorządów oraz perspektywę inwestycyjną funduszy inwestycyjnych.

Cel strategiczny ma zostać osiągnięty przez wypełnianie pięciu celów głównych związanych $\mathrm{z}$ obrotem instrumentami finansowymi oraz towarami, usługami posttransakcyjnymi, nowymi usługami biznesowymi i działaniami organizacyjnymi. Nowa strategia rozwoju Giełdy w Warszawie wygląda na bardzo dopracowaną, wyznacza szczegółowe cele i działania, które mają być podejmowane ,aby je zrealizować.

\section{Podsumowanie}

Od czasu powstania Giełdy Papierów Wartościowych w Warszawie w 1991 r. udało się stworzyć w Polsce sprawnie funkcjonujący rynek kapitałowy. Fakt ten należy rozpatrywać $\mathrm{w}$ kategoriach jednego $\mathrm{z}$ największych sukcesów transformacji gospodarczej w naszym kraju. Największą zaletą polskiego rynku kapitałowego jest to,

\footnotetext{
$53<$ http://www.gpw.pl/gpw2020> [dostęp: 29.04.2014].
} 
że posiada pełne zaplecze instytucjonalne i legislacyjne oraz bogatą i różnorodną ofertę instrumentów finansowych, która w znaczący sposób zwiększa możliwość wyboru form inwestowania. Niewątpliwie istotnym wydarzeniem było utworzenie w 2007 r. alternatywnego rynku NewConnect notującego dzisiaj blisko 450 spółek. Wiele podmiotów dzięki pozyskaniu kapitału mogło dynamicznie realizować strategię rozwoju i spełniając kryteria dopuszczeniowe, przechodzić na rynek regulowany. Tak samo ważne było uruchomienie w 2009 r. rynku obligacji korporacyjnych i komunalnych Catalyst, który pozwolił wielu przedsiębiorstwom i gminom zdobyć zasoby finansowe.

Przeprowadzona przy użyciu najważniejszych mierników analiza prowadzi do konstatacji, że rola Giełdy Papierów Wartościowych w Warszawie w gospodarce Polski jest znaczna, a polski rynek kapitałowy można już nazywać rynkiem dojrzałym. Wpływ na Giełdę zarówno czynników mikroekonomicznych, jak i makroekonomicznych, pozostaje w naszym kraju bardzo duży. Warto również zauważyć, że warszawska Giełda Papierów Wartościowych zamierza w dalszym ciągu zwiększać swój udział w gospodarce krajowej dzięki realizacji strategii rozwoju „GPW.2020”. Plany zostania centrum finansowym Europy Środkowo-Wschodniej tylko potwierdzają tą tezę. 